\title{
Effect of habitat structure on the most frequent echinoderm species inhabiting coral reef communities at Isla Isabel National Park (Mexico)
}

\author{
B. Hermosillo-Nuñez ${ }^{1,2,3,5}$, F. Rodríguez-Zaragoza1 ${ }^{1}$, M. Ortiz², C. Galván-Villa1,
}

\author{
A. Cupul-Magaña ${ }^{4}$ and E. Ríos-Jara ${ }^{1}$
}

'Laboratorio de Ecosistemas Marinos y Acuicultura, Departamento de Ecología, Centro Universitario de Ciencias
Biológicas y Agropecuarias, Universidad de Guadalajara, Carretera a Nogales Km. 15,5, Las Agujas Nextipac,
Zapopan CP 45110, Jalisco, México
2Instituto Antofagasta, Laboratorio de Modelamiento de Sistemas Ecológicos Complejos (LAMSEC), Universidad de
Antofagasta, P.O. Box 170, Antofagasta, Chile
${ }^{3}$ Programa de Doctorado en Ciencias Aplicadas, Mención Sistemas Marinos Costeros, Facultad de Recursos del Mar,
Universidad de Antofagasta, P.O. Box170, Antofagasta, Chile
${ }^{4}$ Departamento de Ciencias Biológicas, Centro Universitario de la Costa, Universidad de Guadalajara, Av.
Universidad 203, Del. Ixtapa, CP 48280, Pto. Vallarta, Jalisco, México
${ }^{5}$ Corresponding author. E-mail: brendahermozillo@gmail.com, brenda.hermosillo@uantof.cl. Tel./Fax: + 56552637804

Keywords: Benthos, Conservation evaluation, Habitat management, Invertebrates, Marine Protected Area, Subtidal.

\begin{abstract}
The spatial distribution and abundance of the seven most abundant species of echinoderms (Diadema mexicanum, Centrostephanus coronatus, Eucidaris thouarsii, Isostichopus fuscus, Pharia pyramidatus, Phataria unifascialis and Acanthaster ellisii) were evaluated in coral communities of Isla Isabel National Park (Mexico). Biological (corals and other benthic groups) and physical (rocks and boulders) structural elements of the habitat were evaluated to determine their relationship to these species. Our results show that species composition and abundance varied among sampling sites and between seasons. Also were obtained significant differences in the echinoderm assemblage among sites across seasons. Similar results were detected for the environmental variables related to benthic habitat structure. D. mexicanum, P. unifascialis, E. thouarsii and C. coronatus were the main contributors to the species abundance and distribution in Isla Isabel. Most echinoderm species were positively related to the coverage of different coral species, algae and various types of benthic organisms as well as to physical benthic variables. These outcomes suggest that the spatial distribution and abundance of these echinoderms are explained by the habitat structure, which should be used to design conservation and management strategies for coral communities.
\end{abstract}

Nomenclature: Kerstitch and Bertsch (2007).

Abbreviations: BVI-Biological Value Index, PERMANOVA-Permutational Multivariate Analysis of Variance, RDARedundancy Analysis, VIF-Variance Inflation Factor.

\section{Introduction}

Studies examining the variation of marine species and its relationship to the benthic habitat structure allow us to determine which factors explain the variation of the distribution and abundance of these species (e.g., Entrambasaguas et al. 2008, Kopp et al. 2012). These factors can consist of both biological and environmental variables, which act differently at different spatial and temporal scales (Legendre and Legendre 1998, Chapman and Underwood 2008). Increases in spatial variability and diversity lead to increased resource availability and biodiversity within habitats. Habitat heterogeneity therefore promotes coexistence through resource partitioning among species (Rosenzweig 1995, Tilman and Kareiva 1997), and is positively correlated with biodiversity and ecosystem functioning (Tylianakis et al. 2008). However, local habitat specificity and changes in habitat quality also influence the composition and abundance of species (Gaston 1994). Hence, quantifying how species differ over multiple spatial scales allows us to focus on the variety of ecological processes that influence organisms (Chapman and Underwood 2008).

Echinoderm species are abundant both in coral reef communities as in the intertidal and shallow subtidal areas around the world, associated with various types of substrates such as sand, mud, rocks, corals, and even wood (Solís-Marín 2008, Ríos-Jara et al. 2008). Likewise, they play different roles in food webs, as carnivores, herbivore, or detritivores (Roberts et al. 2003, Luna-Salguero and Reyes-Bonilla 2010). Due to these broad functional roles, some echinoderms are considered keystone species in different marine ecosystems, controlling the distribution and abundance of other benthic species, and even demonstrating effects on the community structure (Paine 1969, Herrero-Pérezrul et al. 2008) or constituting part of keystone species complexes in various marine ecosystems (Ortiz et al. 2013). 
Many studies have shown that the distribution and abundance of echinoderms are determined by larval settlement and recruitment (Clemente et al. 2009), biological interactions (Hagen and Mann 1992, McClanahan 1998, Alves et al. 2001), temperature (Tyler et al. 2000), salinity (Drouin et al. 1985), harvesting (Hasan 2005) and disease (Dumont et al. 2004). However, few studies have assessed how the structural properties (biological and physical) of benthic habitats affect the distribution and abundance of echinoderms (Entrambasaguas et al. 2008, Alvarado et al. 2012).

In the Mexican Pacific, most studies of echinoderms have assessed their taxonomy (e.g., Honey-Escandón et al. 2008, Granja-Fernández and López-Pérez 2012) and community structure (e.g., Reyes-Bonilla et al. 2008, Luna-Salguero and Reyes-Bonilla 2010). In the coral communities of Isla Isabel National Park, Ríos-Jara et al. (2008) evaluated the distribution and abundance of 31 echinoderm species. Unfortunately this contribution did not assess quantitatively the relationship between the structural elements of coral communities and their level of influence on the spatial distribution and abundance of echinoderms. Recently, Rodriguez-Zaragoza et al. (2011) have shown that the coral communities contribute to increase the heterogeneity of the benthic habitats around the island, promoting the diversity of reef fishes. Therefore, it is expected that on Isabel Island the richness and abundance of the most common echinoderms will be higher in more complex habitats (coral communities), which contribute to increasing the availability of food and refuges.

The aim of the current work was to assess the effect of the biological and physical elements of the habitat (environmental conditions) on the spatial and temporal distribution of the abundance of the most common echinoderm species in the island. It is relevant to mention that these species represent up to $58 \%$ of the total echinoderm abundance of Isla Isabel (sensu Rios-Jara et al. 2008) and they are also conspicuous spe- cies in coral communities of the tropical eastern Pacific (e.g., Alvarado and Chiriboga 2008, Pérez-Ruzafa et al. 2013). The information obtained in this study could be extrapolated and compared with other coral communities and used for developing management strategies focused on the conservation of the marine ecosystem of Isla Isabel National Park and other marine protected areas.

\section{Materials and methods}

\section{Description of the study area}

Isla Isabel $\left(21^{\circ} 53^{\prime} 40^{\prime \prime} \mathrm{N}\right.$ and $\left.105^{\circ} 53^{\prime} 00^{\prime \prime} \mathrm{E}\right)$ is located in the tropical eastern portion of the Pacific Ocean, $28 \mathrm{~km}$ off the coast of Nayarit state (Mexico) (Fig. 1). This zone is a transition between the California Current, the North Equatorial Current and the Gulf of California's water mass (Badan 1997). The seawater around the island is mostly oligotrophic with a salinity of $33-35 \%$, and sea surface temperature fluctuates between $26^{\circ} \mathrm{C}$ and $29^{\circ} \mathrm{C}$ (CONANP 2005). The selected sampling sites correspond to those areas previously described by Rodríguez-Zaragoza et al. (2011). The coral communities on Isla Isabel are mainly dominated by the genera Porites, Pocillopora, Pavona and Psammocora and are distributed between depths of 1.6 and $11 \mathrm{~m}$. For a more detailed description of the geomorphological and oceanographic properties of Isla Isabel, see Galván-Villa et al. (2010) and RodríguezZaragoza et al. (2011).

\section{Sampling}

The field work was carried out in February (winter) and June (summer) of 2009, considering 9 sites around Isla Isabel (Fig. 1). At each site, were quantified the density of echi-

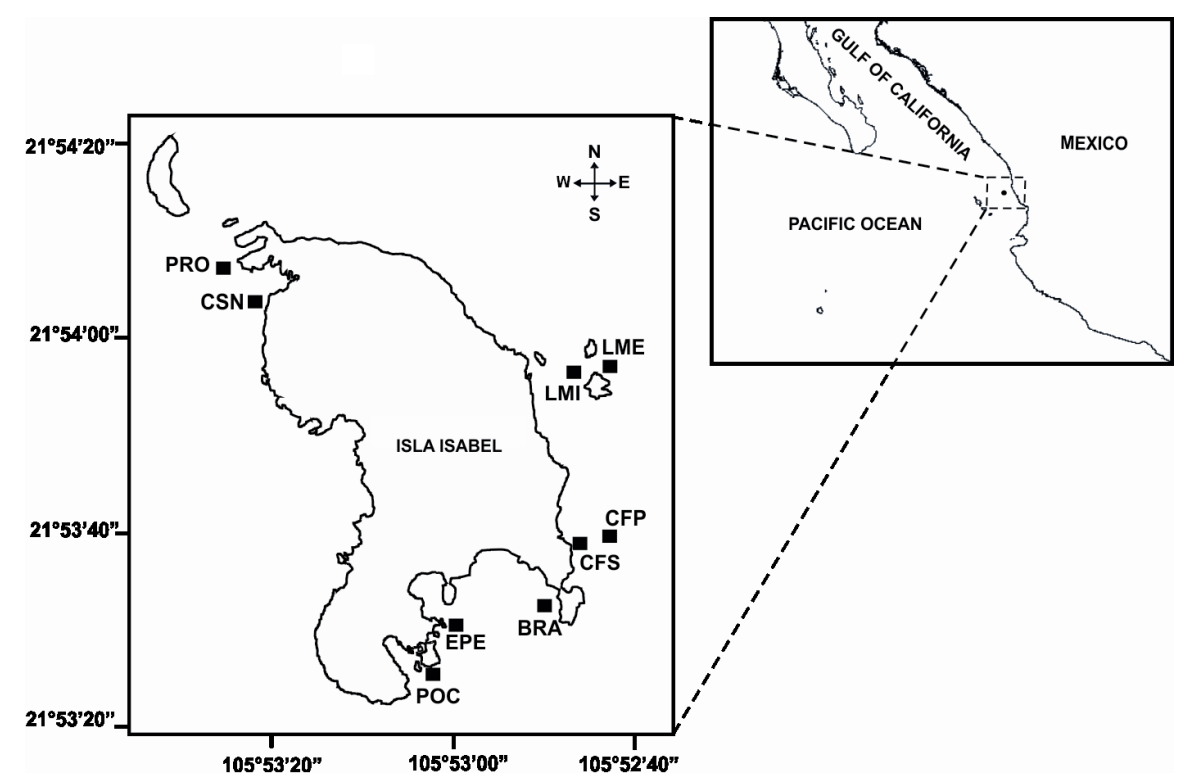

Figure 1. Study area and sampling sites at Isla Isabel National Park, Mexico. Full squares show the location of sampling sites. Site codes: POC - Pocitas; EPE - Ensenada Pescadores; BRA - Bahía Rabijuncos; CFP - Costa Fragata Profundo; CFS - Costa Fragata Somero; LMI - Las Monas Interno; LME - Las Monas Externo; PRO - Punta Rocosa; and CSN - Caleta Sin Nombre. 
noderms, the coverage of corals and other benthic groups, the substratum type and the depth along 5 transects per site and season. A total of 90 transects were conducted parallel to the shore in shallow waters between depths of 3 and 15 $\mathrm{m}$. Different sampling strategies were applied per transect: (1) Diurnal visual censuses $(20 \times 2 \mathrm{~m})$ were conducted to register the density of the following seven species echinoderms: Diadema mexicanum, Centrostephanus coronatus, Eucidaris thouarsii, Pharia pyramidatus, Phataria unifascialis, Acanthaster ellisii and Isostichopus fuscus. (2) Videotransects $(20 \times 0.4 \mathrm{~m})$ were recorded $0.4 \mathrm{~m}$ above the bottom to register the benthic habitat structure (environmental variables). From each video, 40 frames were randomly sub-sampled, and 50 fixed points from each frame were used to estimate the cover of hard corals (Pocillopora, Porites, Pavona and Psammocora), as well as the coverage of hydrocorals, bryozoans, octocorals, sponges, fleshy macroalgae, encrusting calcareous algae, articulated calcareous algae, turf, other sessile organisms, rocks, sand, and coral rubble. (3) The topographic complexity was assessed in each transect with a $10 \mathrm{~m}$ chain based on the chain-link method (Aronson et al. 1994). (4) The total number of cavities (as available refuges) was quantified in four quadrats $(1 \mathrm{~m} \times 1 \mathrm{~m})$ situated at intervals of $5 \mathrm{~m}$. Five cavities of different sizes were selected in each quadrat. The largest and smallest diameter and depth were measured in situ to estimate the average surface and volume using an ellipsoid shape. Based on these measurements, it was possible to assess the availability of refuges: number of cavities, cavity area $\left(\mathrm{cm}^{2}\right)$, cavity volume $\left(\mathrm{cm}^{3}\right)$, cavity number $\times$ cavity area, and cavity number $\times$ cavity volume. Depth (m) measurements were performed once per transect and are reported as the average for each site.

\section{Statistical procedures}

The spatial and temporal variation of the observed echinoderm species abundance was assessed through a permutational multivariable analysis of variance (PERMANOVA) (Anderson et al. 2008). The species abundance was fourthroot transformed prior to performing the multivariate analysis. PERMANOVA was conducted using a Bray-Curtis similarity matrix constructed based on the abundance of each species (ind $/ 40 \mathrm{~m}^{2}$ ). Our PERMANOVA design was based on two crossed factors (season and site, with two and nine levels, respectively), using a type I model (fixed factors). Statistical significance of terms and interactions was assessed running 9,999 permutations. Three additional PERMANOVA designs were also implemented to compare the average species richness and abundance as well as the environmental variables. The first was carried out using a Euclidean distance matrix with previously fourth-root transformed data. It was based on the design of the PERMANOVA described above to evaluate the spatial and seasonal changes in the main benthic habitat structural elements. Under the second, the depth and topographic complexity variables, such as the cavity number, cavity area $\left(\mathrm{cm}^{2}\right)$, cavity volume $\left(\mathrm{cm}^{3}\right)$, cavity number $\times$ cavity area, and cavity number $\times$ cavity volume, were fourthroot transformed and normalized to $\mathrm{Z}$-values to construct a
Euclidean distance matrix. One-way PERMANOVA was only performed spatially (by site) because the measurements were only conducted in winter, assuming that these variables would not change between seasons. Finally, the third followed a two-way design with crossed factors but was designed in a univariate manner. It was developed based on a Euclidean distance matrix to assess the changes in the average species richness and abundance (Anderson et al. 2008). All PERMANOVA tests were conducted using the software PRIMER V6.1 (Clark and Gorley 2006) following the criteria of Anderson et al. (2008).

A two-way similarity percentage (SIMPER) analysis was performed to compare the contributions of the species within and between sampling sites. SIMPER analysis is based on the Bray-Curtis index for estimating the average dissimilarity between pairs of sample groups and determining the contributions to the average similarity within each group (Clarke and Warwick 2001). Similarly, the biological value index (BVI) (Sanders 1960) - modified by Loya-Salinas and Escofet (1990) - was used to determine the importance of each species of echinoderm on Isla Isabel. The BVI indicates the dominance by species based on ranks and scores.

A canonical redundancy analysis (RDA) was carried out to assess the relationship between the spatial-temporal variation of the seven echinoderm species and the benthic habitat structure at the site scale for each sampling time (Legendre et al. 2005). The biological variables were one $Y$ vector generated from the total density (number of individuals) of each species. Environmental variables were organized into a $X$ matrix using the mean values of the coverage of benthic organisms and substrate types estimated from videotransects, as well the average depth, rugosity, number, area and volume of cavities. The RDA ordination was developed using the software CANOCO v4.5 (terBraak and Smilauer 2002), assuming a linear relationship between biological and environmental components. The Trace statistic indicated the variation of $Y$ explained by $X$. Stepwise forward selection was conducted to identify the environmental variables that best explained the variation in $Y$. Multicollinearity was evaluated among the environmental variables because it could modify the RDA model outputs. Only environmental factors with Pearson correlation $(r)$ values below 0.90 were selected. The RDA estimation was realized using a variance inflation factor (VIF) of less than 10 to avoid severe multicollinearity (Chatterjee et al. 2000). The RDA outputs were obtained after running 9,999 permutations. All variables used in RDA are summarized in Appendix A.

\section{Results}

The results of our analyses showed that the seven investigated echinoderm species display high spatial and seasonal variation around Isla Isabel. In general, all of the species exhibited low densities except for D. mexicanum, which was recorded at all sampling sites during both seasons. Regarding the total echinoderm abundance, the Costa Fragata Profundo (CFP) (during winter and summer), Las Monas Externo (LME) (during summer) and Las Monas Interno (LMI) (dur- 
Table 1. PERMANOVA outputs of the spatial-temporal variation of echinoderm assemblage and habitat structure at Isla Isabel National Park, Mexico. Several PERMANOVA designs were built: 1) multivariate two-way crossed PERMANOVA was used to compare the echinoderm assemblage and the benthic habitat structure based on morphofunctional benthic groups; 2) multivariate one-way PERMANOVA was utilized to compare the benthic geomorphological features based on topographic complexity, shelter availability and depth; 3) univariate two-way crossed PERMANOVA was applied to compare the average echinoderm species richness and abundance. Bold numbers correspond to a statistical significance $\mathrm{p}<0.05$.

\begin{tabular}{ccccrr}
\hline \multicolumn{1}{c}{ Source } & Pseudo-F & $p$ & Source & Pseudo-F & $p$ \\
\hline $\begin{array}{c}\text { Multivariate analysis } \\
\text { Echinoderm assemblage }\end{array}$ & & & Univariate analyses \\
Echinoderm species richness & & & \\
Season & 7.4802 & 0.0004 & Season & 11.945 & 0.0008 \\
Site & 2.5191 & $\mathbf{0 . 0 0 0 7}$ & Site & 2.5945 & 0.0134 \\
Season $\times$ Site & 2.2854 & $\mathbf{0 . 0 0 2 2}$ & Season $\times$ Site & 2.53 & 0.0172
\end{tabular}

Benthic habitat structure

$\begin{array}{lll}\text { Season } & 23.759 & \mathbf{0 . 0 0 0 1} \\ \text { Site } & 7.5756 & \mathbf{0 . 0 0 0 1} \\ \text { Season } \times \text { Site } & 4.5645 & \mathbf{0 . 0 0 0 1}\end{array}$

Echinoderm abundance

$\begin{array}{lrr}\text { Season } & 0.09554 & 0.7554 \\ \text { Site } & 3.0013 & \mathbf{0 . 0 0 6 7} \\ \text { Season } \times \text { Site } & 1.3996 & 0.2131\end{array}$

Benthic geomorphological features
Site
5.1709
0.0001

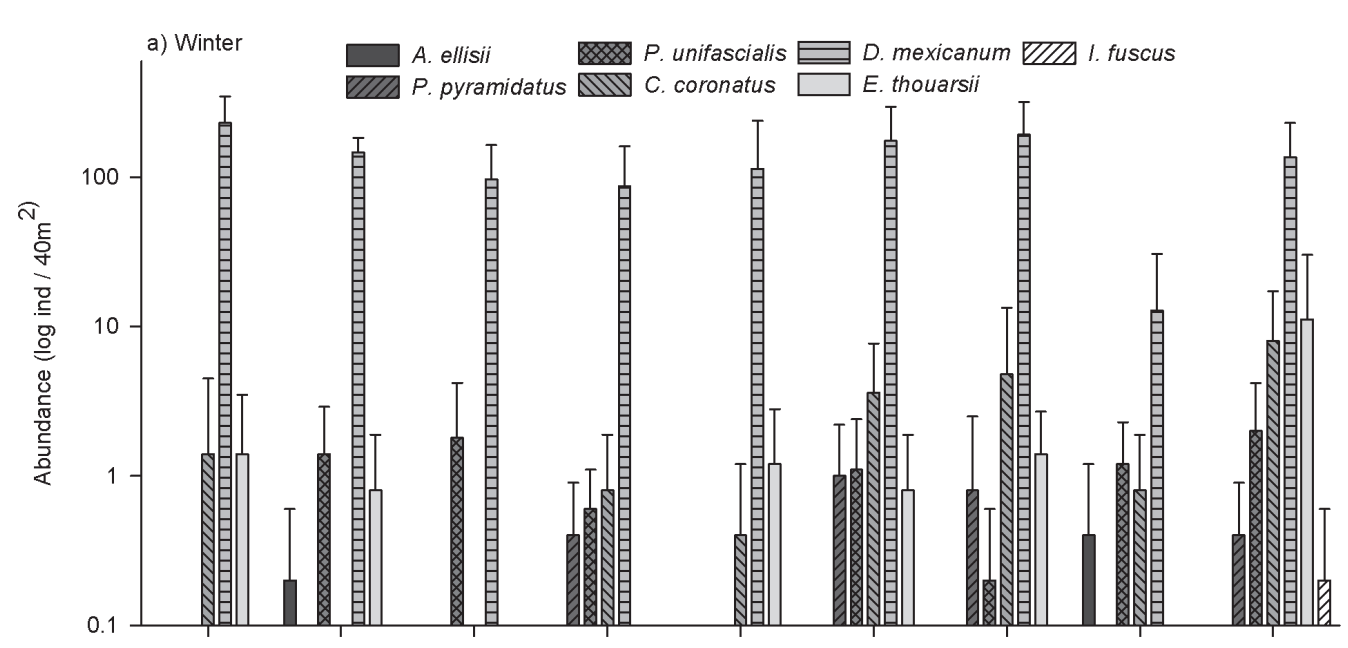

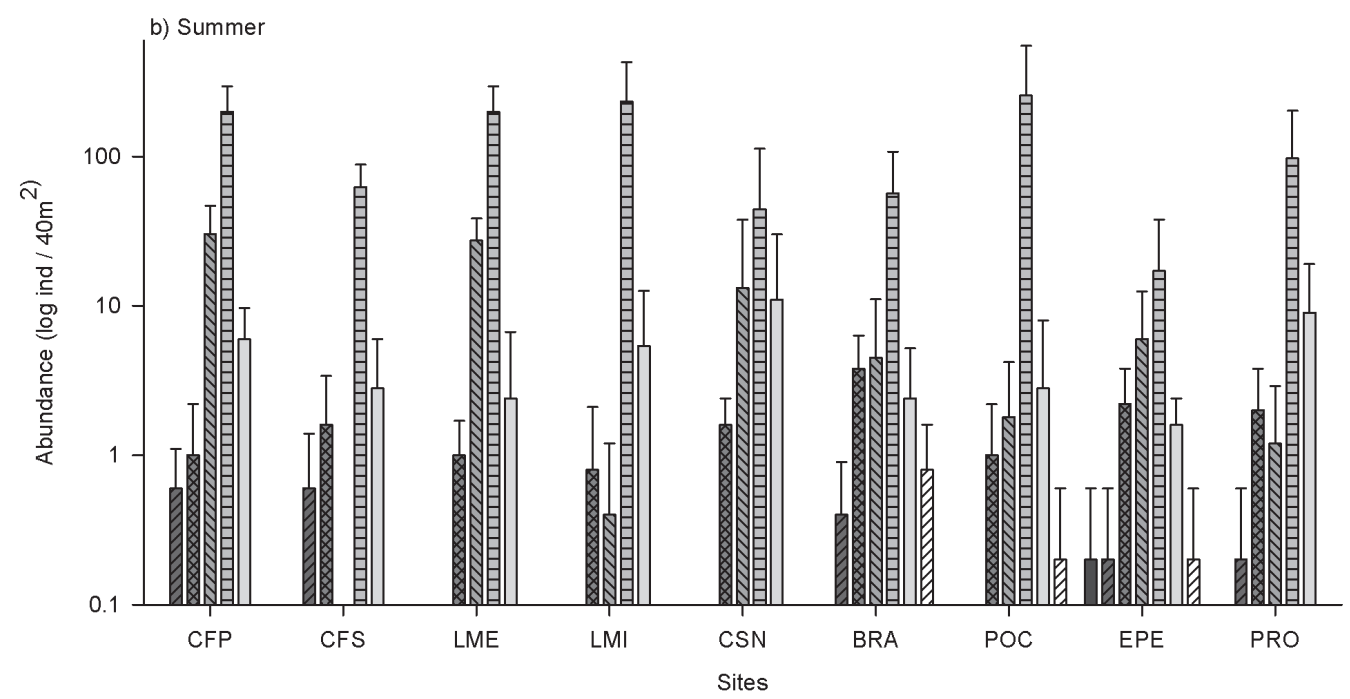

Figure 2. Echinoderm species composition and abundance by site and season at Isla Isabel. Mean values and standard deviations are shown. Species composition and abundance in winter (a), and summer (b). 

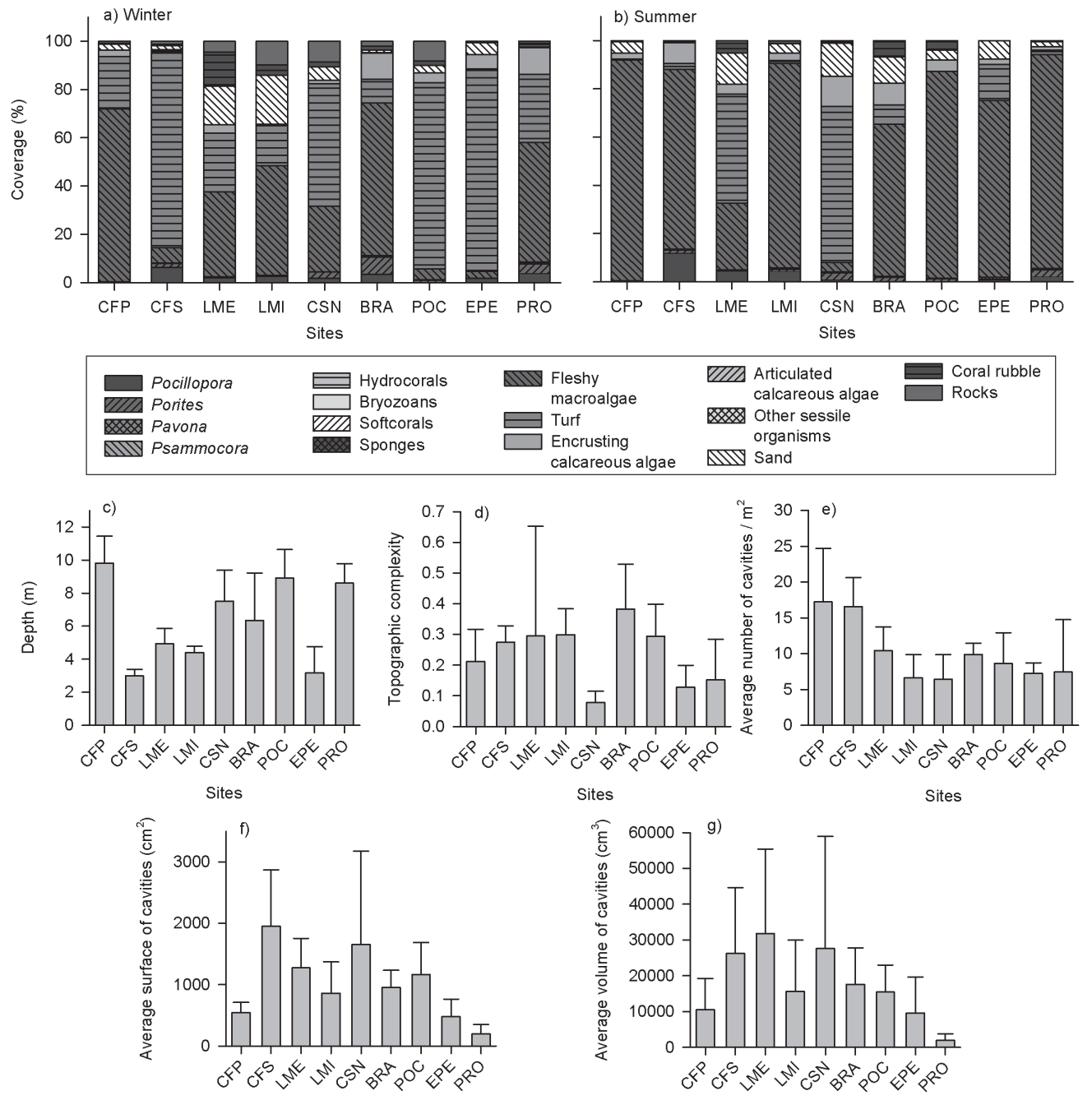

Sites

Sites

Figure 3. Benthic habitat structure and geomorphological features per site and season at Isla Isabel. Coverages of benthic morphofunctional groups in winter (a) and summer (b). Measures of depth (c), topographic complexity (d), average number of cavities (e), average surface of cavities (f), and average volume of cavities (g). In Fig 2c-g the mean values and standard deviations are shown.

ing summer) sites presented the highest values, while the lowest density was observed at Ensenada Pescadores (EPE) during summer (Fig. 2). The total species richness (S) also displayed high spatial and seasonal variability, and it was observed that the site Ensenada Pescadores (EPE) site presented all seven species of echinoderms during summer. In contrast, the lowest species richness was recorded at Las Monas Externo (LME) during winter (LME) (Fig. 2).

The two-way crossed PERMANOVA showed significant differences in the Season $\times$ Site interaction (Table 1). This finding suggests that the species composition and abundance were explained by changes in benthic habitat heterogeneity between sites across climatic seasons. Pairwise comparisons of the Season $\times$ Site interactions across Sites showed that all sites presented significant differences. In contrast, pairwise comparison of the Season $\times$ Site interaction through Seasons showed that the Costa Fragata Profundo, Las Monas Externo, Las Monas Interno and Caleta Sin Nombre sites presented significant differences, while the other sites did not exhibit seasonal changes (Appendix A, Table A1).

The average species richness also showed significant differences with the interaction Season $\times$ Site $($ Table 1). Pairwise comparisons of the Season $\times$ Site interaction across Sites showed that Punta Rocosa presented the largest significant differences among the investigated reef sites. Additionally, pairwise comparisons of the Season $\times$ Site interaction through Seasons revealed that Costa Fragata Profundo and Las Monas Externo exhibited significant changes across seasons (Appendix A, Table A2). The average abundance of echinoderms was also significantly different among sites, but not between seasons or according to the interaction of these factors (Table 1). Furthermore, paired comparisons revealed that the sites that generated differences were Costa Fragata Profundo, Ensenada Pescadores, Las Monas Externo, Bahía Rabijuncos and Las Monas Interno (Appendix A, Table A3). 

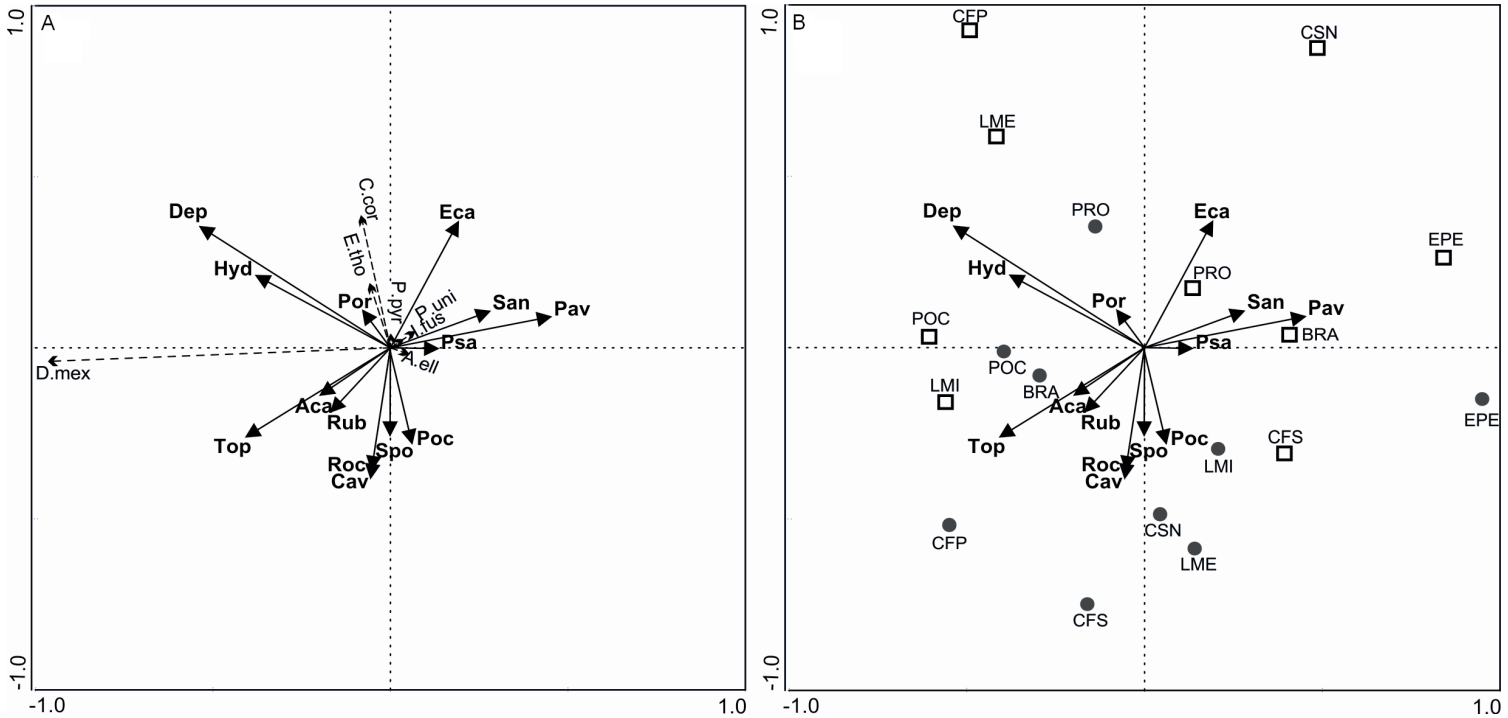

Figure 4. RDA analysis of spatial and temporal variation of seven echinoderm species at Isla Isabel National Park, Mexico. A. Ordination of echinoderm species and habitat variables. B. Ordination of sites and habitat variables Dashed line arrows represent the echinoderm species, and solid line arrows show habitat variables. Winter sampling sites are shown as black circles, and summer sampling sites are shown as squares. Species codes: D.mex - Diadema mexicanum, C.cor - Centrostephanus coronatus, E.tho - Eucidaris thouarsii, P.pyr - Pharia pyramidatus, P.uni - Phataria unifascialis, A.ell - Acanthaster ellisii and I.fus - Isostichopus fuscus. Habitat variable codes: Dep - depth, Top - topographic complexity Hyd - hydrocorals, Cav - cavity area, Eca - encrusting calcareous algae, San - sand, Pav - Pavona, Psa - Psammocora, Poc - Pocillopora, Por - Porites, Spo - sponges, Roc - rocky, Rub - coral rubble, Aca - articulate calcareous algae. Sites codes correspond to show in Fig. 1.

The benthic habitat structure was significantly different in the interaction of Season $\times$ Site (Table 1). Pairwise comparison of the Season $\times$ Site interaction through Sites showed that all sites presented significant differences compared to the other sites. Similarly, pairwise comparison of the Season $\times$ Site interaction across Seasons showed that all sites exhibited significant changes in habitat structure between seasons (Appendix A, Table A4). These habitat structure differences can be observed in Fig. 3a-b, where the benthic morphofunctional groups and substrate types have distinct coverage among sites through the seasons. Fleshy macroalgae and turf presented the highest changes. Otherwise, spatial analysis of the habitat's geomorphological features detected significant differences among sites (Table 1). Pairwise comparisons among Sites showed that all the sites were significantly different (Appendix A, Table A5). The variation of depth, topographic complexity and shelter availability among sites is shown in Fig. 3c-g.

The two-way SIMPER analysis showed that D. mexicanum, $P$. unifascialis, E. thouarsii and C. coronatus made the largest contributions to the average similarity within sites and to the average dissimilarity among sites across seasons (summer and winter) (Appendix B, Table B1, Table B2). Likewise, concerning the biological value indices (BVIs) obtained for the sites in winter, D. mexicanum and C. coronatus presented highest scores, followed by $P$. unifascialis, E. thouarsii and $P$. pyramidatus. In contrast, D. mexicanum, $C$. coronatus and $E$. thouarsii showed the highest BVI scoring in summer (Appendix C, Table C1). In both analyses, D. mexicanum contributed more than $50 \%$ of all species assessed at all sites over seasons.
The RDA ordination presented a good fit and high statistical significance $($ Trace $=0.980, p=0.001)$. This analysis also revealed significant spatial and temporal variation of the echinoderm assemblage. In the RDA's biplots, the first axis mainly showed spatial partitioning among sites, while the second axis indicated a clear temporal separation between the summer and winter samplings (Fig. 4a). RDA forward selection detected the depth, topographic complexity, Pavona, cover, encrusting calcareous algae, average cavity area and Pocillopora cover as the most relevant environmental variables for explaining the spatial-temporal variation in the echinoderm (Fig. 4b, Appendix D, Table D1). P. unifascialis showed a positive relationship with the cover of Pavona, Psammocora, and sandy substrate. During summer, P. pyramidatus, E. thouarsii and C. coronatus presented the highest abundances. These echinoderms displayed a positive relationship with the cover of encrusting calcareous algae and Porites, but they were negatively related to Pocillopora, the average cavity area, sponges and coral rubble. The sea urchin D. mexicanum did not exhibit a significant change in abundance between seasons, but this species did present a positive relationship with depth, topographic complexity and the cover of articulated calcareous algae and hydrocorals (Fig. 4b). Finally, given the little strength of the vectors for I. fuscus and A. ellisii (Fig. 4b), these species showed a very weak relationship with environmental variables.

\section{Discussion}

Many studies have recognized habitat heterogeneity as an important factor structuring benthic marine communities, de- 
termining the richness, spatial and temporal distribution, density, and coexistence of species (Attrill et al. 2000, Kelaher 2003). This relationship has been observed in the echinoderms of the tropical Pacific, which demonstrate an increased species richness and abundance associated with increases in benthic habitat heterogeneity (Bolaños et al. 2005, GonzálezMedina et al. 2006).

The findings of the current work reveal the relationship between the physical and biological characteristics of the benthic habitat and the distribution and abundance of the seven most frequent species of echinoderms around Isla Isabel. These species are also representative of similar ecosystems in the Gulf of California and other places of tropical eastern Pacific (Holguín-Quiñones et al. 2008, Pérez-Ruzafa et al. 2013). Therefore, within these regions, some of the general patterns found in this work would be expected in comparable environments (i.e., coral communities) inhabited by these seven species of echinoderms.

The seasonal variability of the seven echinoderm species suggests that they respond to temporal and spatial changes in benthic reef habitats, as during winter algae dominate turfs, whereas fleshy macroalgae are more abundant during summer. Some of the trends observed in the changes in the abundance and distribution of these echinoderm species may be explained by the presence of food or escape from predation (Sala 1997, Alves et al. 2001). It is widely recognized that the presence of coral increases benthic habitat heterogeneity, providing conditions for shelter, food and reproduction (Bell and Galzin 1984, Rodríguez-Zaragoza et al. 2011). The echinoderms studied here would be favored by these habitat characteristics. For example, it was demonstrated in this work that $P$. unifascialis was positively correlated with the coverage of Psammocora and Pavona corals, while P. pyramidatus, E. thouarsii and C. coronatus were related to coverage of Porites corals. This probably explains why these species are more abundant in areas that have a moderate live coral cover, as was demonstrate in this work. Nevertheless, the low densities detected for A. ellisii and I. fuscus in Isla Isabel restrict us to propose robust conclusions on these species.

The SIMPER and BVI analyses showed that the echinoid species contributed greatly to the detected pattern, in addition to being widely distributed around Isla Isabel. In particular, the echinoids $D$. mexicanum and $C$. coronatus were the dominant species at all the study sites where adult organisms formed aggregations in cracks and caves. These species feed on different species of algae, sponges and other benthic invertebrates (Sammarco 1982, Tuya et al. 2004). The abundance of these echinoids was higher at sites where there were patches of Pocillopora spp. on reefs and rocky reefs with a high availability of shelter (cracks and hollows), potentially allowing them to avoid depredation pressure (Benedetti-Cecchi et al. 1998, Hooker et al. 2005). The echinoid C. coronatus was most abundant during winter at sites dominated by encrusting calcareous algae. However, this pattern does not agree with that reported by Vance (1979), who described C. coronatus as an herbivorous species that feeds on fleshy algae, tunicates and sponges, avoiding encrusting calcareous algae. This disparity shows that further biological and ecological analyses of $C$. coronatus are needed. In the case of the echinoid $E$. thouarsii, Hooker et al. (2005) indicated that this species is a common inhabitant of cracks, as observed in the current work. Additionally, it shows a positive relationship with Porites corals, as the presence of these corals increases the availability of food for this sea urchin. E. thouarsii is known to feed on coral polyps, coralline algae and even juveniles of mollusk species (Glynn et al. 1979, Glynn and Wellington 1983).

In this study the asteroids showed lower densities than the echinoids. The species $P$. pyramidatus and $P$. unifascialis were the most abundant, which agrees with what has previously been reported for Isla Isabel (Ríos-Jara et al. 2008) and for other benthic communities in the Gulf of California (González-Medina et al. 2006, Herrero-Pérezrul et al. 2008). However, the SIMPER and BVI analyses showed that $P$. unifascialis was the most common asteroid at Isla Isabel. In general terms, this seastar species presented a significant relationship with higher cover of Pavona and Psammocora corals. This pattern can be explained by the observation that these corals provide sufficient food for this seastar, as demonstrated by Luna-Salguero and Reyes-Bonilla (2010). The seastar A. ellisii is one of the most significant corallivorous species on coral reefs of the tropical eastern Pacific (Glynn 1981). Nevertheless, in this study A. ellisii presented a weak relationships with environmental variables due to its low abundance $\left(0.042 \mathrm{ind} / 40 \mathrm{~m}^{2}\right)$ which is lower than that reported on other rocky reefs of the Gulf of California ( $0.15 \mathrm{ind} / 40$ $\mathrm{m}^{2}$ ) (Luna-Salguero and Reyes-Bonilla 2010). The low density of this species would indicate a reduction of depredation pressure upon hard corals, as reported in other areas of the Gulf of California (Barham et al. 1973, Reyes-Bonilla and Calderón-Aguilera 1999).

The sea cucumber I. fuscus also showed a weak relationships with environmental variables because it had low abundance. Nuño-Hermosillo (2003) suggested that this species is commonly found on rocky substrates. At Isla Isabel, the average density of $I$. fuscus reached $0.04 \mathrm{ind} / 40 \mathrm{~m}^{2}$, which is lower than the abundance reported in other communities of the Gulf of California (1.12 ind/40 m²) (Reyes-Bonilla et al. 2008). This result indicates the importance of conducting detailed studies on I. fuscus to assess its population dynamics for management proposes. This is relevant because I. fuscus is a protected species under the Official Mexican Norm (NOM-ECOL-059-2010) and an endangered species within the IUCN Red List of threatened species (Mercier et al. 2013).

The current work demonstrated that the structure of the benthic habitat at Isla Isabel National Park influences the diversity of the most abundant echinoderm species found in coral communities associated with rocky reefs. Our outcomes agree with those reported by Rodríguez-Zaragoza et al. (2011), who showed that each studied reef site (which were the same as those examined in the present work) has particular characteristics that determine the composition and abundance of reef fish species. Thus, the findings presented here demonstrate the importance of preserving the structural heterogeneity of the reef habitats at Isla Isabel and also for other comparable reef communities. This information could 
be considered in the design of conservation management strategies for this kind of marine ecosystem since the coral species determine principally the environmental condition for echinoderm species.

Because echinoderms perform important functional roles on rocky and coral reefs, such as controlling the distribution and abundance of other benthic species, bioturbation of sediment and bioerosion, among others (Herrera-Escalante et al. 2005, Herrero-Pérezrul et al. 2008, Vardaro et al. 2009), the study of the distribution of the most abundant echinoderm species improves our understanding of the coral community dynamics (Zamorano and Leyte-Morales 2005, Alvarado and Chiriboga 2008). Although our findings should be considered an improvement of our knowledge of the coral ecosystems, it is still necessary to conduct further studies that integrate ecologically these echinoderm species as a part of the trophic web, identifying functional groups, keystone species complexes and emergent ecosystem properties and macrodescriptores.

Acknowledgements. We thank M. R. Priego-Arenas, A. Martínez-Ricart, P. Gómez-Petersen and C. V Pérez-de Silva for colaboration in the field work and also thank Comision Nacional de Áreas Naturales Protegidas (CONACYT), specially J. A. Castrejón-Pineda, G. Pérez-Lozano and C. Robles-Carrillo for your help in the field work. This study was financed by the Programa de Mejoramiento del Profesorado (PROMEP) (103.5/08/2919, 103.5/10/927) and the Universidad de Guadalajara (P3E 2009-08634). The first author is grateful for the scholarship granted by PROMEP (103.5/10/927) and the Red de Medio Ambiente \& Sustentabilidad (ReMAS)-CONACYT (ReMAS-2010-018).

\section{References}

Alvarado, J.J. and A. Chiriboga. 2008. Distribución y abundancia de equinodermos en las aguas someras de la Isla del Coco, Costa Rica (Pacífico Oriental). Rev. Biol. Trop. 56: 99-111.

Alvarado, J.J., H.M. Guzman and O. Breedy. 2012. Distribution and diversity of echinoderms (Asteroidea, Echinoidea, Holothuroidea) in the islands of the Gulf of Chiriqui, Panama. Rev. Biol. Mar. Oceanog. 47: 13-22.

Alves, F.M.A., L.M. Chicharo, E. Serrão and A.D. Abreu. 2001. Algal cover and sea-urchin spatial distribution at Madeira Island (NE Atlantic). Sci. Mar. 65: 383-392.

Anderson, M.J., R.N. Gorley and K.R. Clarke. 2008. PERMANOVA+ for PRIMER: guide to software and statistical methods. Plymouth: PRIMER-E. pp. 274.

Aroson, R.B., P.J. Edmunds, W.F. Precht, D.W. Swanson and D.R Levitan. 1994. Large scale, long-term monitoring of Caribbean coral reefs: simple, quick, inexpensive techniques. Atoll. Res. Bull. 421:1-19.

Attrill, M.J., J.A. Strong and A.A. Rowden. 2000. Are macroinvertebrate communities influenced by structural complexity? Ecography 23: 114-121.

Barham, E.G., R.W. Gowdy and F.H. Wolfson. 1973. Acanthaster (Echinodermata, Asteroidea) in the Gulf of California. Fish B-NOAA 71: 927-942.
Badan, A. 1997. La corriente costera de Costa Rica en el pacífico mexicano. En: M.F. Lavín (eds) Contribuciones a la oceanografía física en México. Monografía No. 3, Unión Geofísica Mexicana. pp. 99-112.

Bell, J.D. and R. Galzin. 1984. Influence of live coral covers on coralreef fish communities. Mar. Ecol. Prog. Ser. 15: 265-274.

Benedetti-Cecchi, L., F. Bulleri and F. Cinelli. 1998. Density dependent foraging of sea urchins in shallow subtidal reefs on the west coast of Italy (western Mediterranean). Mar. Ecol. Prog. Ser. 163: $203-211$

Bolaños, N., A. Bourg, J. Gómez and J.J. Alvarado. 2005. Diversidad y abundancia de equinodermos en la laguna arrecifal del Parque Nacional Cahuita, Caribe de Costa Rica. Rev. Biol. Trop. 53: 285-290.

Chapman, M.G. and A.J. Underwood. 2008. Scales of variation of gastropod densities over multiple spatial scales: comparison of common and rare species. Mar. Ecol. Prog. Ser. 354: 147-160. doi:10.3354/MEPS07205

Chatterjee, S.A., A.S. Hadi and B. Price. 2000. Regresion Analysis by Example. John Wiley and Sons, New York, USA.

Clarke, K.R. and R.M. Warwick. 2001. Change in Marine Communities: an approach to statistical analysis and interpretation. PRIMER-E, Plymouth, UK. pp. 172.

Clarke, K.R. and R.N. Gorley. 2006. Primer v6: user manual/tutorial. Primer-E Ltd, Plymouth, UK.

Clemente, S., J.C. Hernández and A. Brito. 2009. Evidence of the top-down role of predators in structuring sublittoral rocky-reef communities in a marine protected area and nearby areas of the Canary Islands. ICES J. Mar. Sci. 66: 64-71.

CONANP. 2005. Programa de conservación y manejo del Parque Nacional Isla Isabel, México. Comisión Nacional de Áreas Naturales Protegidas. pp. 164

Drouin, G., J. Himmelman and T. Béland. 1985. Impact of tidal salinity fluctuations on echinoderm and mollusc populations. Can. J. Zool. 63: 1377-1387.

Dumont, C.P., J.H. Himmelman and M.P. Russell. 2004. Sea urchin mass mortality associated with algal debris from ice scour. In: N. Heinzeller (ed), Echinoderms. Taylor \& Francis Group: London. pp. 177-182.

Entrambasaguas, L., A. Pérez-Ruzafa, J.A. García-Charton, B. Stobart and J.J. Bacallado. 2008. Abundance, spatial distribution and habitat relationships of echinoderms in the Cabo Verde Archipelago (eastern Atlantic). Mar. Freshwater Res. 59: 477488 .

Galván-Villa, C.M., J.L. Arreola-Robles, E. Ríos-Jara and F.A. Rodríguez-Zaragoza. 2010. Ensamblajes de peces arrecifales y su relación con el hábitat bentónico de la Isla Isabel, Nayarit, México. Rev. Biol. Mar. Oceanog. 45: 311-324.

Gaston, K.J. 1994. Rarity. Chapman \& Hall, London.

Glynn, P.W. 1981. Acanthaster population regulation by a shrimp and a worm. Proceedings of the Fourth International Coral Reef Symposium 2: 607-612.

Glynn, P.W., G.M. Wellington and C. Birkeland. 1979. Coral reef growth in the Galápagos: Limitation by sea urchin. Science 203: 47-49.

Glynn, P.W. and G.M. Wellington. 1983. Corals and Coral Reefs of the Galapagos Islands (with and annotated list of the scleractinian corals of the Galapagos by J. W. Wells). Univ. California Press, Berkeley.

González-Medina, M.J., O. Holguín-Quiñones and G. de la CruzAguero. 2006. Variación espacio-temporal de algunos invertebrados (Gastropoda, Bivalvia y Echinodermata) de fondos 
someros del Archipiélago Espíritu Santo, B.C.S., México. Cienc. Mar. 32: 33-44.

Granja-Fernández. M.R. and R.A. López-Pérez. 2012. Biodiversidad de ofiuroideos (Echinodermata: Ophiuroidea) de Oaxaca y Chiapas, México. En: Recursos acuáticos costeros del sureste, Vol. 1: 356-370.

Hagen, N. and K. Mann. 1992. Functional response of the predators American lobster Homarus americanus (Milne-Edwards) and Atlantic wolffish Anarhichas lupus (L) to increasing numbers of the green sea urchin Strongylocentrotus droebachinesis (Müller). J. Exp. Mar. Biol. Ecol. 159: 89-112.

Hasan, M.H. 2005. Destruction of a Holothuria scabra population by overfishing at Abu Rhamada Island in the Red Sea. Mar. Environ. Res. 60: 489-511- doi:10.1016/J.MARENVRES.2004.12.007

Herrera-Escalante, T., López-Pérez, R.A., Leyte-Morales, G.E. 2005. Bioerosion caused by the sea urchin Diadema mexicanum (Echinodermata: Echinoidea) at Bahías de Huatulco, western Mexico. Rev. Biol. Trop. 53: 263-273.

Herrero-Pérezrul, M.D., H. Reyes-Bonilla, A. GonzálezAzcárraga, C.E. Cintra-Buenrostro and A. Rojas-Sierra. 2008. Equinodermos. In: G.D. Danemann and E. Ezcurra (eds) Bahía de Los Ángeles. INE-PRONATURA, Ensenada, B.C., México. pp. 339-361.

Holguín-Quiñones, O.E., F.J. González-Medina, F. Solís-Marín and E.F. Félix-Pico. 2008. Variación espacio-temporal de Scleractinia, Gorgonacea, Gastropoda, Bivalvia, Cephalopoda, Asteroidea, Echinoidea y Holothuroidea, de fondos someros de la isla San José, Golfo de California. Rev. Biol. Trop. 56: 11891199.

Honey-Escandón, M., F.A. Solís-Marín and A. Laguarda-Figueras. 2008. Equinodermos (Echinodermata) del Pacífico Mexicano. Rev. Biol. Trop. 56: 57-73.

Hooker, Y., F.A. Solís-Marín and M. Lleellish. 2005. Equinodermos de las Islas Lobos de Afuera (Lambayeque, Perú). Rev. Per. Biol. 12: 77-82.

Kelaher, B.P. 2003. Changes in habitat complexity negatively affect diverse gastropod assemblages in coralline algal turf. Oecologia. 135: 431-441.

Kerstitch, A. and H. Bertsch. 2007. Sea of Cortez Marine Invertebrates: a guide for the Pacific coast, México to Peru. Se Challengers, Monterey, California.

Kopp, D., Y. Bouchon-Navaro, M. Louis, L. Pierre and C Bouchon. 2012. Spatial and temporal variation in a Caribbean herbivorous fish assemblage. J. Coastal. Res. 28(1A): 63-72

Legendre, P. and L. Legendre. 1998. Numerical Ecology. 2nd English edition. Elsevier, Amsterdam.

Legendre, P., D. Borcard and P. Peres-Neto. 2005. Analyzing beta diversity: partitioning the spatial variation of community composition data. Ecol. Monogr 75:435-450.

Loya-Salinas, D.H. and A. Escofet. 1990. Aportaciones al cálculo del Índice de Valor Biológico (Sanders, 1960). Contribution to the calculation of the Biological Value Index (Sanders, 1960). Cienc. Mar. 16:97-115.

Luna-Salguero, B.M. and H. Reyes-Bonilla. 2010. Estructura comunitaria y trófica de las estrellas de mar (Echinodermata: Asteroidea) en arrecifes rocosos de Loreto, Golfo de California, México. Hidrobiológica 20: 127-134

Mercier, A., J.F. Hamel, T.G. Toral-Granda, J.J. Alvarado, P.E. Ortiz and M. Benavides 2013. Isostichopus fuscus. In: IUCN 2013. IUCN Red List of Threatened Species. Version 2013.2. <www. iucnredlist.org>. Downloaded on 04 January 2014
McClanahan, T.R. 1998. Predation and the distribution and abundance of tropical sea urchin populations. J. Exp. Mar. Biol. Ecol. 221: 231-255.

Nuño-Hermosillo, A. 2003. Estructura y dinámica poblacional del pepino de mar Isostichopus fuscus en la costa de Jalisco, México. Tesis de Maestría. Posgrado en Ciencias Biológicas, Universidad de Guadalajara.

Ortiz, M., R. Levins, L. Campos, F. Berrios, F. Campos, F. Jordán, B. Hermosillo, J. González and F. Rodríguez. 2013. Identifying keystone trophic groups in benthic ecosystems: Implications for fisheries management. Ecol. Indic. 25: 133-140.

Paine, R.T. 1969. A note of tropic complexity and community stability. Am. Nat. 103: 91-93.

Pérez-Ruzafa, A., J.J. Alvarado, F.A. Solís-Marín et al. 2013. Latin America echinoderm biodiversity and biogeography: Patterns and affinities. In: J.J Alvarado and F. A. Solís-Marín (eds) Echinoderm research and diversity in Latin America. SpringerVerlag Berlin Heidelberg [doi: 10.1007/978-3-642-20051-9_16]

Reyes-Bonilla, H. and L.E. Calderon-Aguilera. 1999. Population density, distribution and consumption rates of three corallivores at Cabo Pulmo Reef, Gulf of California, Mexico. Mar. Ecol. 20: 347-357.

Reyes-Bonilla, H., M.D. Herrero-Pérezrul, S. González-Romero, A. González-Peralta and Y. Ramírez-Hernández. 2008. Abundance of the brown sea cucumber Isostichopus fuscus at the National Park Bahía de Loreto, México. Rev. Biol. Trop. 56: 265-271.

Ríos-Jara, E., C.M. Galván-Villa and F.A. Solís-Marín. 2008 Equinodermos del Parque Nacional Isla Isabel, Nayarit, México. Rev. Mex. Biodivers. 79: 131-141.

Roberts, D., Gebruk, A., Levin, V., and Manship, B. A. D. 2003 Feeding and digestive strategies in deposit-feeding holothurians. Oceanography and Marine Biology: An Annual Review: Volume 38: An Annual Review, 38, 257.

Rodríguez-Zaragoza, F.A., A.L. Cupul-Magaña, C.M. Galván-Villa, E. Ríos-Jara, M. Ortiz, E.G. Robles-Jarero, E. López-Uriarte and J.E. Arias-González. 2011. Additive partitioning of reef fish diversity variation: a promising marine biodiversity management tool. Biodiver. Conserv. 20: 1655-1675

Rosenzweig, M.L. 1995. Species Diversity in Space and Time Cambridge University Press, Cambridge.

Sala, E. 1997. Fish predators and scavengers of the sea urchin Paracentrotus lividus in marine protected areas of the northwestern Mediterranean. Mar. Biol. 129-531-539.

Sanders, H.L. 1960. Benthic studies in Buzzard Bay. III. The structure of the soft-bottom community. Limnol. Oceanogr. 5:38-153.

Sammarco, P.W. 1982. Echinoid grazing as a structuring force in coral communities: whole reef manipulations. J. Exp. Mar. Biol. Ecol. 61: 31-55.

Solís-Marín, F.A. 2008. Catálogo de los equinodermos recientes de México (Fase II). Universidad Nacional Autónoma de México. Informe final SNIB-CONABIO proyecto No. DC016 México.

ter Braak, C.J.F. and P. Šmilauer. 2002. CANOCO reference manual and CanoDraw for Windows user's guide: software for canonical community ordination (version 4.5) Microcomputer Power, USA.

Tilman, D. and P. Kareiva. 1997. Spatial ecology: the role of space in population dynamics and interspecific interactions. Princeton University Press, Princeton (New Jersey).

Tuya, F., A. Boyra and R.J. Haroun. 2004. Blanquizales en Canarias: La explosión demográfica del erizo Diadema antillarum en los fondos rocosos de Canarias. BIOGES, Canarias, España 
Tyler, P.A., C.M. Young and A. Clarke. 2000. Temperature and pressure tolerances of embryos and larvae of the Antarctic sea urchin Sterechinus neumayeri: potential for deep-sea invasion from high latitudes. Mar. Ecol. Prog. Ser. 192: 173-180.

Tylianakis, J.M., T.A. Rand, A. Kahmen, A.M. Klein, N. Buchmann, J. Perner and T. Tscharntke. 2008. Resource Heterogeneity Moderates the Biodiversity-Function Relationship in Real World Ecosystems. Plos Biol 6(5): e122. doi:10.1371/journal. pbio.0060122.

Vance, R.R. 1979. Effects of grazing by the sea urchin, Centrostephanus coronatus, on prey community composition. Ecology. 60: 537-546.

Vardaro, M.F., H.A. Ruhl and K.L. Smith Jr. 2009. Climate variation, carbón flux, and bioturbation in the abyssal North Pacific. Limnol.Oceanogr. 54: 2081-2088.

Zamorano, P. and G.E. Leyte-Morales. 2005. Cambios en la diversidad de equinodermos asociados al arrecife coralino de La Entrega, Oaxaca, México. Cienc. Mar. 9:19-28.

Received May 2, 2014
Revised January 6, 2015
Accepted March 25, 2015

\section{Appendix A}

Table A1. PERMANOVA's pairwise test of Season $\times$ Site's interaction, comparing the variation of echinoderm species composition and abundance at Isla Isabel, Mexico.

Table A2. PERMANOVA's pairwise test of Season $\times$ Site's interaction, comparing the variation of average species richness among sites over seasons at Isla Isabel, Mexico.
Table A3. PERMANOVA's pairwise test to compare the variation of echinoderms average abundance among sites at Isla Isabel, Mexico.

Table A4. PERMANOVA's pairwise test of Season x Site's interaction to compare the variation of benthic habitat structure among sites over seasons at Isla Isabel, Mexico.

Table A5. Pairwise test of Site to compare the habitat geomorphological features at Isla Isabel, Mexico.

\section{Appendix B}

Table B1. Two-way SIMPER results of average similarity and dissimilarity among sites across seasons at Isla Isabel National Park, Mexico.

Table B2. Two-way SIMPER results of average similarity and dissimilarity within and among sites across seasons at Isabel Isla Isabel Park, Mexico.

\section{Appendix C}

Table C1. Biological value index (IVB) estimated by season at Isla Isabel National Park, México.

\section{Appendix D}

Table D1. Community, environmental and spatial variables considered for the Canonical RDA.

The files may be downloaded from www.akademiai.com. 